\title{
Izaradari/Revenue Farming System in Eighteenth and Nineteenth Centuries in Baroda State
}

Hridesh Ranga Mourya*

Temporary Assistant Professor, Department of History, Faculty of Arts, the Maharaja Sayajirao University of Baroda, Vadodara, Gujarat, India

DOI: $10.36347 /$ sjahss.2020.v08i02.006

| Received: 17.02.2020 | Accepted: 25.02.2020 | Published: 29.02.2020

*Corresponding author: Hridesh Ranga Mourya

\section{Abstract}

The izaradari/revenue farming system in India introduced during the medieval period and later revived under the British and the Marathas and subsequently gets meta-morphed when put into application in the eighteenth and nineteenth centuries. The paper attempts to throw light on the evolution and characteristics of izaradari/revenue farming system in Gaekwad State of Baroda in the eighteenth and nineteenth centuries. This was the time when the administration of the Baroda State was in its nascent stage. Hence the land revenue collection had not yet been formed. The eighteenth and nineteenth centuries in Baroda State had witnessed a period of significant changes and rapid experimentation in the revenue administration.

Keywords: Izaradari/revenue farming, Baroda State, mulkagiri, chauth, sardeshmukhi, zamindari, jagirdari, biddingauction.

Copyright @ 2020: This is an open-access article distributed under the terms of the Creative Commons Attribution license which permits unrestricted use, distribution, and reproduction in any medium for non-commercial use (NonCommercial, or CC-BY-NC) provided the original author and source are credited.

During the medieval period, the territories of Patan, Ahmedabad, Champaner, Baroda, Bharuch, Surat and Rajpipla (Nandod) were under the direct control of Bahadur Shah (1526-1536), then the Sultan of Gujarat. He had introduced the custom of farming the revenue through contracts (ijara). Although this system was abolished by Akbar but revived under the early Maratha rulers [1]. During the 18th century ijaradari system became a common form of revenue assessment and collection when the right of collecting land revenue sold by public auction to the highest bidders or izaradars.

The revenue system introduced by Akbar's finance minister Todarmal was more or less continued by Marathas in Gujarat. The revenue system of Todarmal was based on survey and settlement while traditional form of revenue collection was consisted of zamindari, jagirdari, mulkagiri[2], chauth [3], sardeshmukhi [4] etc. In fact, the Marathas were not satisfied with the Todarmal's settlement hence they re-

\footnotetext{
${ }^{1}$ Desai, G. H., \& Clarke, A. B., (1923). The Gazetteer of the Baroda State, Volume I. Bombay: The Times Press. 427 \& 429

${ }^{2}$ Collection of arbitrary tribute by troops in form of land tax.

${ }^{3}$ Chauth - Maratha claim of revenue for protection levied at $25 \%$ of total production.

${ }^{4}$ Sardeshmukhi - A tax of 10 per cent by Maratha as hereditary tax.
}

started the traditional way of revenue collection. Thus, land was granted to the zamindars, jagirdars or izaradars who enjoyed the land which they received in term of gifts or bidding for some years [5]. They were free to decide the share of revenue as per their desire. They gradually authorised the collection of revenue to the matdar (village headman)[6]. Thus izaradari system gradually introduced in the Maratha territories where the revenue was mainly fixed by izaradars. In this system, the king was greedy to extract the revenue as much as possible from izaradar and the izaradar extracting the revenue as much as possible from peasant[7].

The early history of Baroda State commenced with the downfall of Mughal Empire and rise of Maratha power [8 ]. The Baroda State was formed during the eighteenth century. The first Maratha invasion of Gujarat took place in 1705. In 1712, Khanderao Dabhade was the first of the Marathas to be granted the rights of revenue collection from Gujarat in

\footnotetext{
5 Desai, G. H., (1919-20). Vadodara Rajya Prantic Sarva Sangrah, Kadi Prant. Baroda: Baroda State Press. 212

${ }^{6}$ Desai, G. H., (1919-20). 212

${ }^{7}$ Ibid.

8 Playne, S., (1921-22). Indian State; A Biographical, Historical and Administrative Survey. London E. C.: The Foreign and Colonial Compiling and Publishing Co. 9
} 
form of chauth and sardeshmukhi[9]. He was assisted by his officer Damaji Gaekwad who distinguished himself so bravely and skilfully in ensuing conflicts. Because of his sheer bravery, Damaji Gaekwad was given the title of 'Shamsher Bahadur' meaning 'illustrious swordsman' [10]. In the year 1721, Damajirao Gaekwad died and succeeded by his nephew Pilajirao Gaekwad[11]. The king of Satara granted Pilajirao Gaekwad a right to collect the tribute in Gujarat [12]. In 1723, Pilajirao Gaekwad defeated the governor in Surat after which tribute in Gujarat was regularly levied. He became the first Gaekwad to establish the control over Baroda and much of Gujarat. Therefore, he is considered as the founder of Baroda State [13]. He secured the right to collect the tribute from the territories of Baroda, Nandod, Champaner, Bharuch, Surat etc. [14]. He made Songadh as the headquarter of his State till 1766. It was his son Damaji Rao II who made Baroda the capital of Gaekwads[15]. After the Maratha rule established in Gujarat, the revenue was divided between Peshwa and Gaekwad in 1751-52. They both adopted the izaradari system. The izardar of the district managed individual villages through the Patels who distributed the demand among the cultivators in the manner convenient to them. This system created an extra-ordinary complexity of tenures and system of revenue management [16].

Between 1734 and 1764 the territories of (part of Amreli and Navsari) Gujarat were gradually captured by Damajirao II. He also established his hold in Kadi. After negotiations with local chiefs, the Gaekwads were able to wrest half of the revenues from Ahmedabad and Viramgam Taluka. Gradually, the revenues of northern and central Gujarat and annual revenue from Kathiawad were collected by Gaekwad [17]. Thus, revenue collection became an important feature of control. The nascent Gaekwad State had to rely on external agencies for collection of revenue, which often took the shape of izaradari system or revenue farming system. It is difficult to say absolutely when the izaradari system was introduced into Gaekwad State of Baroda but the data suggests its introduction in the late eighteenth

${ }^{9}$ F. A. H., (1883). Gazetteer of the Bombay Presidency: Volume VII, Baroda. Bombay: Government Central Press. 167-168 and Tait, T. S., (1908). Imperial Gazetteer of India; Baroda. Calcutta: Superintendent of Government Printing, 9

${ }^{10}$ Playne, S., (1921-22). 9

${ }^{11}$ Elliot, F. A. H., (1883). Volume VII. 167-168 and Tait, T. S., (1908). 9

${ }^{12}$ Playne, S., (1921-22). 9

${ }^{13}$ Elliot, F. A. H., (1883). Volume VII. 167-168 and Tait, T. S., (1908). 9

${ }^{14}$ Playne, S., (1921-22). 9

${ }^{15}$ Elliot, F. A. H., (1883). Volume VII. 167-168 and Tait, T. S., (1908). 9

${ }^{16}$ Patel G. D., (1969). The Land Revenue Settlements and The British Rule in India, Ahmedabad: Gujarat University Press. 23

17 Thakar, H. G., (1935). Bandharan Ane Itihas. Baroda: Government Press, 2-3 century when the process of formation of Baroda state was still fluid.

During this period of transition, the revenue farmers or contractors called izaradars were given the responsibility of revenue collection from individual village or group of villages. On certain occasion's whole of mahals or even districts were also leased out to the izaradars. The izaradars often assumed different names and offices such as kamavisdaars, vahivatdars, mamlatdars, desais, mazmudars, amins, patels, potedars etc.[18] Thus, land revenue system had entrusted into the collection of revenue through particular agent where the territories were farmed out to the highest bidders. These holders were granted the right to collect the revenue what could from the peasant and paid the stipulated sum to the state. Thus, the izardari system evolved in the state. The ijaradars, in fact, were not the government officials but the person to whom the right of collection of revenue was granted by government [19]. The Kalambandi/Circular Order of 1827 enjoined that an annual statement of the sum paid to hereditary officers was to be sent in by the ijaradars, together with vouchers and receipts [20].

The revenue was collected both in cash and kind so the peasants were confused that in which terms they have to pay the revenue. The king transferred the authority of land from old land holder to new land holder who could pay more revenue than the old one. The izradars or the sub-izaradars were assisted by Patels so the fixation of land revenue on Patel's land was relatively low. Hence sometime the izaradari of villages was completely authorised to the Patels who by taking this advantage extracted the money from peasant as much as possible [21].

The izaradars were further assisted by the karkuns or clerks. The assigned territories under the izaradars were called as mahal which was divided into several thanas or groups of villages. For instance, the Baroda mahal was consisted of 18 thanas. These thanas were managed by the government official called as thanedar and each village had its mehta. The thanedar was supervising the collection of revenue while the mehta actually collecting it, in which he was checked by a vatandar or hereditary officer, talati or weigher who represented the interest of villagers. The thanedar continued to do their works till 1859-60 when Maharaja Khanderao introduced new revenue policy and police system [22]. The vatandars mean possessors of the offices and were appointed for the security of government and as a convenient means of communication with the inhabitant. They did not

\footnotetext{
${ }^{18}$ Elliot, F. A. H., (1883). Volume VII. 362 \& 413-414

${ }^{19}$ Desai, G. H., \& Clarke, A. B., (1923). The Gazetteer of the Baroda State, Volume II. Bombay: The Times Press. 3

${ }^{20}$ Desai, G. H., \& Clarke, A. B., (1923). Volume II. 4

${ }^{21}$ Desai, G. H., (1919-20). 212

${ }^{22}$ Desai, G. H., \& Clarke, A. B., (1923). Volume II. 4
} 
directly help izaradars in collection of revenue [23]. There were other government officials such as desai and mazmumdar. The desai had to assist in the settlement of revenue and receipt to state. The mazmumdar had to keep the account about the jamabandi of mahal - fiscal unit [24].

The tenure of the farm, which izaradar obtained by bidding at an auction, was for a very limited number of years. Hence, they did not lose any opportunity to improve their position in administration and to making the highest profits. The power of farmers was great as the whole district could be placed under him. He could be civil judge and magistrate and often he could be in possession of fortified places and thanas. $\mathrm{He}$ was collector of taxes and the regulator of their amount [25]. The izaradars were generally not maintaining the records of revenue. If they were maintaining the records, they did not show it to the supreme authority. This is why we do not have the sufficient sources for the study of izaradars[26]. The agreement between the supreme authority and izaradars was made where the izaradar was not losing any chance of corruption. Even they declared their property on the names of their relatives not on their own name. They used themselves to act as a witness of that property. During the last phase of their contract, the izaradars extracted all revenue forcefully from peasant before a certain period because their izara right could be transfer anytime by the supreme authority [27].

Maharaja Khanderao Gaekwad attempted to bring about changes in the land revenue settlements. Khanderao's aim was to abolish the farming or izaradari system. The farmers of revenue were judges, magistrates, military commanders often and collector of revenue. Khanderao's action on administration of the land was threefold: firstly he onslaught on the holder of inam; secondly by abolishing the custom of izaradari system, he introduced a revenue survey, substituting a fixed money payment and a ten years' settlement and thirdly introduced a new system of management [28]. Payment was to be made in cash and a state service was established for the payment of collection of revenue instead of contracting it out to ijaradars. Thus, ijaradari system later abolished by Maharaja Khanderao and the revenue fixed on the basis of land settlement. There were many new features introduced which were not there before [29]. However the land administrative reform undertaken by Khanderao was failed. In fact, the izaradari system continued after the survey and settlement introduced [30].

During the period of Maharaja Malharrao Gaekwad, the new system was worse than the izaradari system. The management of district and revenue was granted by Maharaja Malharrao to his certain court favourites who then became kamavisdars. Even the women could also assume the position of revenue farmer. For instance, Kamasaheb, the daughter of Malharrao, was kamavisdar[31].

It was realised by Sir T Madhavrao, Diwan of Baroda State from 1875-1881, that the revenue farmers made exorbitant demands on the cultivators and often took only a percentage of what they pretended to expect. The fiscal pressure on each village was ascertained with the capabilities of village. Hence it appeared necessary to take such immediate relief [32]. Sir T Madhavrao, in the administration report of 1875 1876 , mentioned that the revenue farming system was congenial to the native rulers. This system was agreeable to both the ministers and the revenue famers. They were either chosen from the motives of favouritism or came from wealthy and influential members of local community. Thus, they had naturally acquired a strong hold. A body of revenue farmers collected the land revenue in almost any manner they like and poured large sum into the treasury. However, it was the great body of ryots who suffered a lot by this system [33]. Sir T Madhavrao further describes his difficulties in dealing with the reforms of this system. He mentioned that a mahal or district managed by a revenue farmer was brought under direct government administration. The revenue farmer's accounts were not often available and if available were not often reliable [34].

Sir T Madhavrao's aims were to simplify and purify the system of taxation. Hence, he abolished the old systems (including izaradari system) and created a new one [35]. He laid the foundation stone of revenue department which later was enhanced by Maharaja Sayajirao III. As a result, the new land revenue systems based on scientific methods of survey and settlement was introduced into the Gaekwad State of Baroda.

\footnotetext{
${ }^{23}$ Desai, G. H., \& Clarke, A. B., (1923). Volume II. 4

${ }^{24}$ Ibid.

${ }^{25}$ Elliot, F. A. H., (1883). Volume VII. 414

${ }^{26}$ Desai, G. H., \& Clarke, A. B., (1923). Volume II. 213

${ }^{27}$ Ibid.

${ }^{28}$ Elliot, F. A. H., (1883). Volume VII. 366-367

${ }^{29}$ Elliot, F. A. H., (1883). Volume VII. 367-370
}

\author{
${ }^{30}$ Elliot, F. A. H., (1883). Volume VII. 370 \\ ${ }^{31}$ Elliot, F. A. H., (1883). Volume VII. 370-371 \\ ${ }^{32}$ Elliot, F. A. H., (1883). Volume VII. 371 \\ ${ }^{33}$ Elliot, F. A. H., (1883). Volume VII. 415 \\ 34 Ibid. \\ ${ }^{35}$ Desai, G. H., \& Clarke, A. B., (1923). Volume II. 432
}

